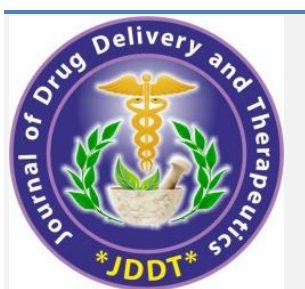

Open Access Full Text Article

Copyright (C) 2021 The Author(s): This is an open-access article distributed under the terms of the CC BY-NC 4.0 which permits unrestricted use, distribution, and reproduction in any medium for non-commercial use provided the original author and source are credited

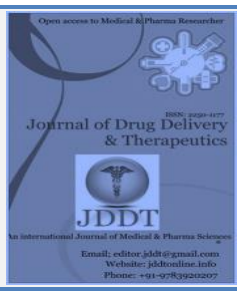

Research Article

\title{
Pharmacognostical and Physiochemical Study on the Leaves of Nyctanthes arbor-tristis Linn
}

\author{
${ }^{1 *}$ Rohit Kumar Bijauliya, ${ }^{1}$ Pushpendra Kannojia, 2 Pankaj Mishra, ${ }^{3}$ Prashant Kumar Singh, 4 Rahul Kannaujia \\ ${ }^{1}$ BIU College of Pharmacy, Bareilly International University, Bareilly-243006, Uttar Pradesh, India \\ ${ }^{2}$ Keshlata College of Pharmacy, Bareilly International University, Bareilly-243006, Uttar Pradesh, India \\ ${ }^{3}$ Lord Buddha College of Pharmacy, Lucknow-226008, Uttar Pradesh, India \\ ${ }^{4}$ Lucknow Model College of Pharmacy, Sadrauna, Lucknow-226009, Uttar Pradesh, India
}

\begin{tabular}{|c|c|}
\hline \multicolumn{2}{|l|}{ Article Info: } \\
\hline 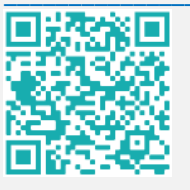 & $\begin{array}{l}\text { Article History: } \\
\text { Received } 06 \text { May } 2021 \\
\text { Review Completed } 19 \text { June } 2021 \\
\text { Accepted } 26 \text { June } 2021 \\
\text { Available online } 15 \text { July } 2021\end{array}$ \\
\hline \multicolumn{2}{|c|}{ Cite this article as: } \\
\hline \multicolumn{2}{|c|}{$\begin{array}{l}\text { Bijauliya RK, Kannojia P, Mishra P, Singh PK, } \\
\text { Kannaujia R, Pharmacognostical and Physiochemical } \\
\text { Study on the Leaves of Nyctanthes arbor-tristis } \\
\text { LinnJournal of Drug Delivery and Therapeutics. 2021; } \\
\text { 11(4):30-34 }\end{array}$} \\
\hline DOI: http://dx.doi & .org/10.22270/jddt.v11i4.4914 \\
\hline
\end{tabular}

*Address for Correspondence:

Mr. Rohit Kumar Bijauliya, Assistant Professor Department of Pharmacognosy, BIU College of Pharmacy, Bareilly International University, Bareilly243006, Uttar Pradesh, India

\section{Abstract}

Aim: To rationalize the macroscopial, microscopical and physico-chemical studies on leaves of plant Nyctanthes arbor-tristis Linn. Methods: The pharmacognostic characters were determined in terms of macroscopy, microscopy and powder microscopy of plant Nyctanthes arbor-tristis leaves. The crude ethanolic extract of leaves of Nyctanthes arbor-tristis Linn. was using physico-chemical parameters, and preliminary phytochemical investigation (TLC). Results: The microscopic study shows the general characteristic of Nyctanthes arbor-tristis leaves. Phytochemical analysis revealed the presence of various phytochemical groups like alkaloids, glycosides, steroids, phenolic, tannins constituents. Conclusion: It can be concluded that the established pharmacognostic profile of Nyctanthes arbor-tristis leaves will be helpful in developing pharmacopoeial standards for correct identification and quality control. The present observation will also be helpful in macroscopical and microscopical on leaves of Nyctanthes arbor-tristis Linn.

Keywords: Nyctanthes arbor-tristis, Pharmacognostical Study, Macroscopial and Microscopical studies

\section{INTRODUCTION:}

Nyctanthes arbor-tristis L. (Oleaceae) is an essential medicinal plant that has been used for a variety of purposes since antiquity. Various parts of this plant have been used as traditional and local medicines. Nyctanthes arbor-tristis is used as a diuretic, digestive, laxative, anti-venom, mild bitter tonic, and expectorant in the Siddhya-Ayurveda, Ayurveda, and Yunani systems of medicine. 1,2. Nyctanthes arbor-tristis Linn. (Division: Magnoliophyta; Class: Magnoliopsida; Order: Lamiales; Family: Oleaceae), commonly known as Harshingar and Night jasmine ${ }^{3}$, is a well-documented plant. It is a terrestrial woody perennial plant with a lifespan of 5-20 years that grows up to 10 meters tall. It is a well-known tree with a wide range of pharmacological activities that is widely cultivated throughout the world in tropical and subtropical regions. 4, 5. It can be found in the outer Himalayas and parts of Jammu and Kashmir, Nepal to the east of Assam, Bengal, and Tripura, which stretch from the central region to the Godavari in the south ${ }^{6}$. It prefers arid and semi-arid climatic conditions and grows in red and black soils with a pH of 5.6$7.5^{7}$.
Nyctanthes arbor-tristis, as previously mentioned, has a wide range of pharmacological activities and the ability to cure a variety of diseases. Since this plant is so essential to humans in their daily lives, it can be a good source of income. As a result, adulteration of this plant with various species of the genus Nyctanthes can occur in order to make more money. As a result, standard criteria for proper authentication of this plant or a part of it have to be established ${ }^{8}$. The aim of this study is to investigate the morphological, microscopical, and physiochemical characteristics of Nyctanthes arbor-tristis leaves in order to ensure that they cannot be easily tampered with.

\section{MATERIALS AND METHODS:}

\subsection{Materials:}

2.1.1 Plant Collection: Fresh leaves of "Nyctanthes arbortristis" Linn was composed from local area of Lucknow (India) in the month July 2019. The plant material identified and authenticated by CSIR- National Botanical Research Institute (NBRI), Lucknow, Authentication No. (LWG) 104617. All the reagents, solvents, and chemicals used are of 
A.R. grade (Merck, Loba, Qualigens) purchased from local supplier.

\subsection{Methods:}

2.2.1 Macroscopical study: The leaves' macroscopic characteristics were observed (appearance, fracture, colour, odour, scale, shape, texture, taste). The technique described by Trease and Evans was used to perform quantitative microscopy ${ }^{9}$.

2.2.2 Microscopical Study: A thin transverse segment of a fresh leaves was prepared and stained with concentrated hydrochloric acid: Phloroglucinol for microscopic examination (1:1). The photographs were taken with great care. The dried leaves were powdered and treated with a $5 \%$ $\mathrm{KOH}$ solution, then stained for 5 minutes with concentrated hydrochloric acid - Phloroglucinol (1:1) and placed in a 50\% glycerine solution. "Histological studies such as category along with tissue preparation, the incidence of quantity classification such as calcium oxalate crystals using a magnification microscope were involved" $10,11,12$.

2.2.3 Preparation of the Plant Extract: "The leaves of Nyctanthes arbor-tristis Linn were dried at room hotness for 25 days along with were ground keen on coarse fine particles among a chopper". "150 gm of coarse powder was macerated through ethanol $(99.9 \% \mathrm{v} / \mathrm{v})$ and kept for 72 hours on area heat $\left(28-30^{\circ} \mathrm{C}\right) "$. The extract was filtered also evaporate towards dehydration at temperature $30-35{ }^{\circ} \mathrm{C}$, the theoretical and practical yield of the extract was also calculated. 13

2.2.4 Phytochemical Analysis: Phytochemical screening of the various extract of plants for the presence of carbohydrate, steroids, glycosides amino acids, saponin and flavonoid, alkaloid, proteins, tannin and phenolic compound which are responsible for the biological activity.

2.2.5 TLC Profile: "Nyctanthes arbor-tristis Linn TLC was performed with a mixture of ethyl acetate: methanol: water (77:15:8) and a solvent method (mobile phase)" using precoated silica gel G plate (stationary phase). For detection, ninhydrin reagents were used. The Rf value was calculated for a separate location. The "thin layer chromatography was conducted and extreme strain" was observed.

2.2.6 TLC Preparation of Extract: "Activation of pre-coated silica gel 60 TLC plates by injection at $110-120^{\circ} \mathrm{C}$ during furnace usage for 30 minutes proceeding to sample spotting". "The sample was applied on 60 TLC capillary silica gel precoated plates". "Plates with a solvent method of ethyl acetate: methanol: water $(77: 15: 8)$ " were residential. The "Rf value of the fraction constituent variable" was detected 14 .

\section{RESULTS:}

3.1Macroscopical Study: The macroscopic and "organoleptic characters of the leaves were experimental, i.e. shape, scale, colour, odour, margin, texture, taste, apex even petiole".

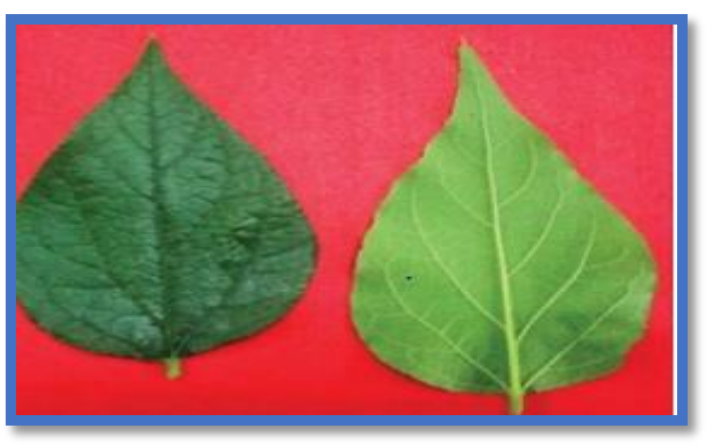

Figure 1: Nyctanthes arbor-tristis leaf

Table 1: Macroscopic study of $N$. arbor-tristis Linn. Leaf

\begin{tabular}{|l|l|}
\hline $\begin{array}{l}\text { Plant part and } \\
\text { characters }\end{array}$ & Observation \\
\hline Part & Leaves \\
\hline Colour & Light to dark green \\
\hline Odour & Indistinct \\
\hline Taste & Bitter and astringent \\
\hline Size & 5 -15 cm long, 2.5-5.7 cm wide \\
\hline Texture & Rough \\
\hline Shape & Heart \\
\hline Base & Oblique \\
\hline Margin & Entire \\
\hline Apex & Acute \\
\hline Venation & Reticulate \\
\hline
\end{tabular}

\subsection{Microscopy Study:}

During the midrib convex project resting on the inferior field, the leaf of Nyctanthes arbor-tristis was cut, also faintly wavy between a thin middle rise going to the superior sector. A small number of collenchymal coatings lie below each other's epidermis, with the superior coating positioned nearby on the curved xylem hole. The unicellular trichomes of various sizes produce cystolite on the bottom of the bear plain layer. Glandular trichomes were also close to a bicellular top overflowing by gloomy tanned satisfied among single-cell shadow.

The higher epidermis of the lamina cell was walled broadly quite instantly with stomata devoid. Two rows of epidermis are seen in the lamina near the midrib. By sinous stockade on spaces, cuticle striated with slanting with regular anomocytic stomata, the cell of the inferior epidermis is smaller in amount than that of the upper one. Two rows of pole cells lie in the higher epidermis, "followed by 7-9 rows of soft parenchyma transversed near vascular bundles often surrounded by parenchyma cell". 


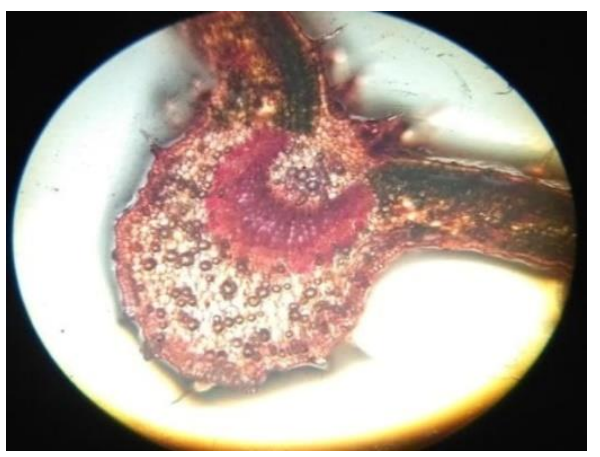

a) T.S. leaves of NAT mid-rib

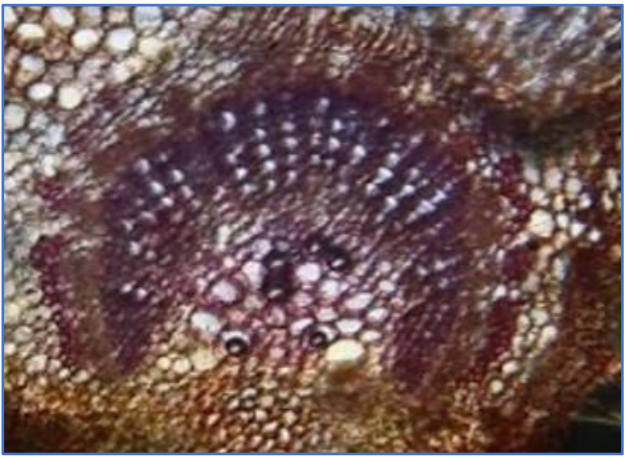

(b) Vascular bundle

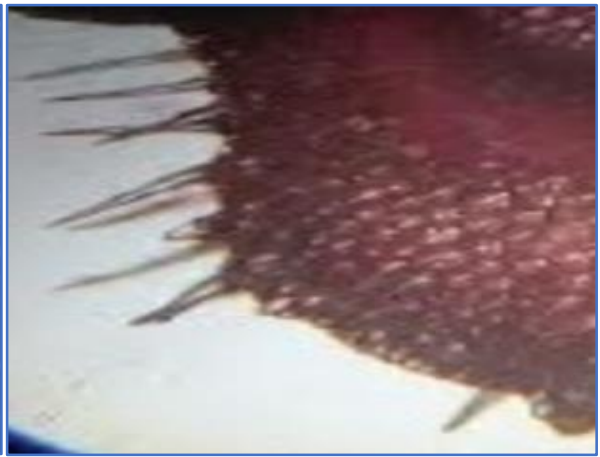

(c) Trichome

Figure 2: T.S. leaves of Nyctanthes arbor-tristis midrib, vascular bundle and trichome

3.3 Powder microscopy: Nyctanthes arbor-tristis "powder microscopy" reveals the occurrence of starch grains, palisade cells, trichomes, phloem and xylem vessels. This includes the histological study of the tissue preparation type, the occurrence of quality characteristics "such as trichome and starch grain using a magnification microscope", for example.

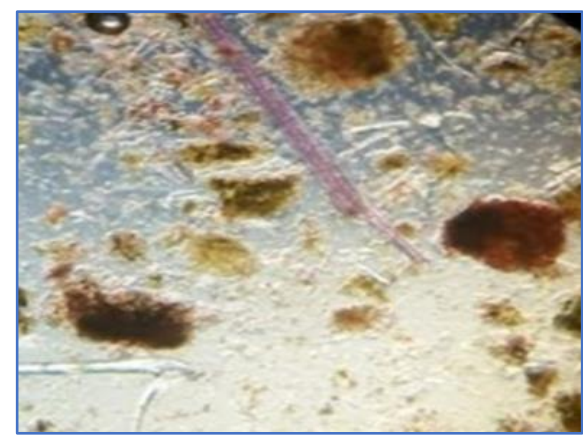

(a) Starch grains

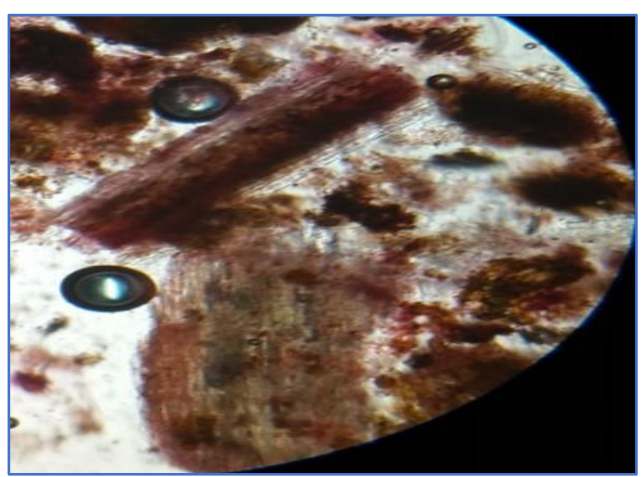

(c) Phloem vessels

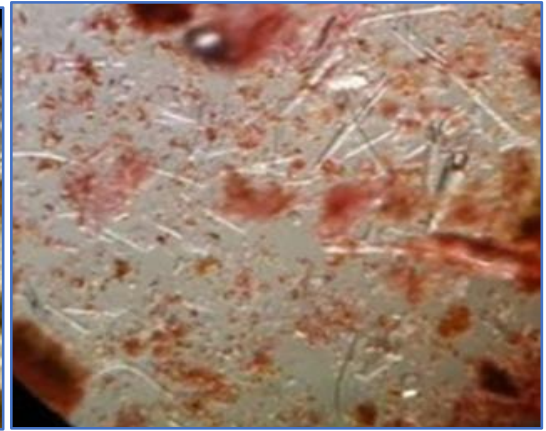

(b) Trichomes

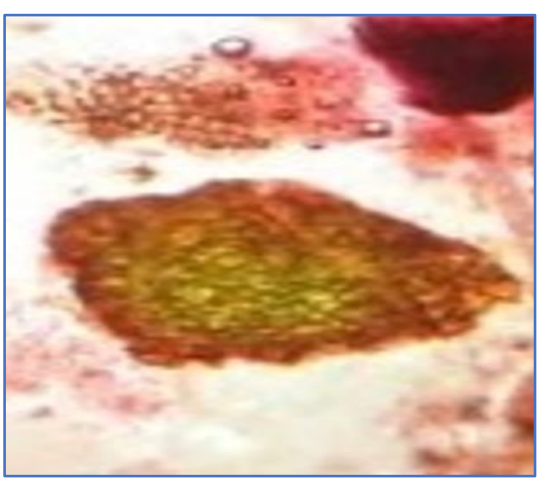

(d) Xylem vessels

Figure 3: Powder microscopy of Nyctanthes arbor-tristis

3.4 Phytochemical Analysis: The crude hydroethanolic extract was screened the present "alkaloids, flavonoids, glycoside, carbohydrate, protein, starch, amino acid, steroid, tannins and saponins using the simple chemical test as reported in a standard reference book". 
Table 2: Phytochemical screening of Nyctanthes arbortristis Linn.

\begin{tabular}{|l|l|l|}
\hline Class of Drug & Chemical test & Results \\
\hline Carbohydrate & $\begin{array}{l}\text { Fehling } \\
\text { Molisch } \\
\text { Benedict }\end{array}$ & Positive \\
\hline Alkaloids & $\begin{array}{l}\text { Dragendroff test } \\
\text { Hagers } \\
\text { Mayer } \\
\text { Wagners }\end{array}$ & Positive \\
\hline Flavonoid & $\begin{array}{l}\text { Alkaline } \\
\text { Lead acetate }\end{array}$ & \\
\hline Glycoside & $\begin{array}{l}\text { Legal test } \\
\text { Killer Killiani }\end{array}$ & Positive \\
\hline Terpenoid and steroid & Salkowski & Positive \\
\hline Protein and amino acid & $\begin{array}{l}\text { Millons test } \\
\text { Ninhydrane }\end{array}$ & Postive \\
\hline Saponin & Foam & Negative \\
\hline Tannin & FeCl3 & Positive \\
\hline
\end{tabular}

3.5 Evaluation of Nyctanthes arbor-tristis leaf extract: "The extract obtained was dark green in colour, greasy with an indistinct odour and bitter in texture". The extracts were "soluble in an organic solvent and were considered in water to be insoluble". The percentage yield was measured and set at $6.48 \% \mathrm{w} / \mathrm{w}$.

Table 3: Observation of Nyctanthes arbor-tristis L. leaf extract

\begin{tabular}{|l|l|}
\hline Extract study & Observation \\
\hline Plant parts & Dried and powdered leaves \\
\hline Extraction process & Simple maceration \\
\hline Solvent & Ethanol $(80 \% \mathrm{v} / \mathrm{v})$ \\
\hline Colour & Dark green \\
\hline Texture & Greasy \\
\hline Odour & Indistinct \\
\hline Soluble & Water and alcohol \\
\hline Insoluble & Acid \\
\hline Practical yield & 3.24 gm \\
\hline Percentage yield & $6.48 \% \mathrm{w} / \mathrm{w}$ \\
\hline
\end{tabular}

3.6 TLC Profile: Thin layer chromatography of purified sample of Nyctanthes arbor-tristis was performed".

Table 4: TLC Finger Printing of ethanolic extract of leaf of Nyctanthes arbor-tristis Spots

\begin{tabular}{|l|l|l|l|}
\hline Solvent system & Solvent run (cm) & Solute run (cm) & Rfvalue \\
\hline Ethyl acetate: methanol: water (77: 15:8) & 7.3 & 7.1 & 0.97 \\
\hline
\end{tabular}

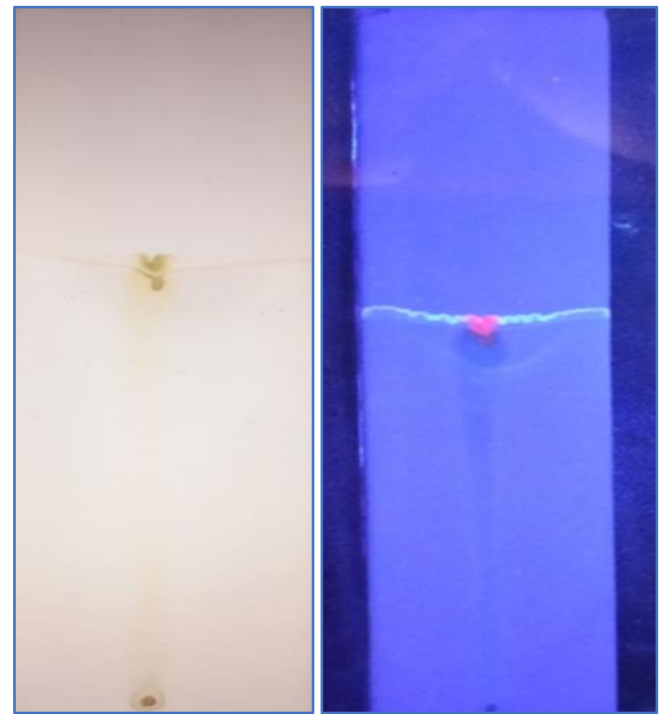

Figure 4: TLC plate of ethanolic extract of Nyctanthes arbor-tristis

\section{DISCUSSION:}

As a part of standardization study, the macroscopically examination of drug was studied. Nyctanthes arbour-tristis leaves are plain, " 5 to $14 \mathrm{~cm}$ long, 2.5 to $7.5 \mathrm{~cm}$ thick, acute to acuminate, ovate, both rough outside, whole margin or distinctly toothed base in circles to very cuneate, venation reticulate", 3-6 pairs of side veins, indistinguishable odour, bitter with astringent taste. The extract was dark green in colour, greasy in texture, with an indistinct smell and a bitter taste. The percentage yield was measured and set at $6.48 \%$ $\mathrm{w} / \mathrm{w}$. The microscopical evaluation of leaves powder showed that it contains characteristics features of vascular bundle, trichome, starch grains, xylem and phloem vessels. Phytochemical extract research has been conducted. In which alkaloid-containing plant extract, "glycoside, flavonoid, carbohydrate, protein and amino acid". Phytochemical screening involves of a thin layer chromatography. The type of constituents present in the extract was obtained from the TLC. The $\mathrm{R}_{\mathrm{f}}$ values discovered from the TLC are the constituents of Flavonoid present in the extract.

\section{CONCLUSION:}

The present study was focused on establishing pharmacognostic standards for the identification and authentication of the Nyctanthes arbor-tristis. Therefore, the outcomes of the above findings will serve as a promising source for laying down pharmacopoeial standards for the future studies and research.

\section{Acknowledgement:}

The authors are thankful to Prof. (Dr.) Pushpendra Kannojia, Department of Pharmacology, BIU College of Pharmacy, Bareilly International University, Bareilly (U.P.), for their valuable guidance. 


\section{Conflict of Interest: Nil}

\section{REFERENCES:}

1. Uniyal SK, Singh KN, Jamwal P, Lal B. Traditional use of medicinal plants among the tribal communities of Chhota Bhangal, Western Himalaya. J Ethnobiol Ethnomed 2006; 2(14):1-8. https://doi.org/10.1186/1746-4269-2-14

2. Rangika BS, Dayananda PD, Peiris DC. Hypoglycemic and hypolipidemic activities of aqueous extract of flowers from Nyctanthes arbor-tristis L. in male mice. BMC Complement Altern Med 2015; 15(1):1-9. https://doi.org/10.1186/s12906015-0807-0

3. Kiew R, Bass P. Nyctanthes is a member of the Oleaceae. Proc Indian Acad Sci (Plant Sci.) 1984; 93(3):349-58.

4. Rani C, Chawla S, Mangal M, Mangal AK, Kajla S, Dhawan AK. Nyctanthes arbor-tristis Linn. (Night Jasmine): a sacred ornamental plant with immense medicinal potentials. Indian J Tradit Knowl 2012; 11(3):427-35.

5. Agrawal J and Pal A. Nyctanthes arbor-tristis Linn-a critical ethnopharmacological review. J Ethnopharmacol 2013; 146(3):645-58. https://doi.org/10.1016/j.jep.2013.01.024

6. Jain PK, Pandey A. The wonder of Ayurvedic medicine-Nyctanthes arbor-tristis. Int J Herbal Med 2016; 4(4):9-17.'
7. Latha PG, Suja SR, Shyamal S, Rajasekharan S. Some hepatoprotective garden plants. Nat Prod Radiance 2005; $4(4): 278-9$.

8. Suresh G. Killedar, Harinath N. More, and Sameer J. Nadaf. Microscopic Evaluation of Leaves of Memecylon umbellatum Burm. Hindawi Publishing Corporation Advances in Agriculture Volume 2014, Article ID 104849, 6 pages https://doi.org/10.1155/2014/104849

9. Trease GE and Evans WC: Pharmacognosy. Harcourt brace \& Co. Asia, Pvt. Ltd., W.B. Saunders Company Ltd., 15th Edition 2002.

10. Shah BN and Seth AK: Pharmacognostic studies of the Lagenaria siceraria (Molina) Standley. International Journal of PharmTech Research. 2010; 2(1):121-4.

11. Kokate CK: Practical Pharmacognosy, Vallabh Prakashan, New Delhi, 4th Edition 1994.

12. Khandelwal KR: Practical Pharmacognosy, Nirali publication, Pune, 18th Edition, 2007.

13. Nirmal SA, Pal SC, Mandal SC, Patil AN. Analgesic and antiinflammatory activity of $\beta$-sitosterol isolated from Nyctanthes arbortristis leaves. Inflammopharmacology 2012; 20(4):219-24. https://doi.org/10.1007/s10787-011-0110-8

14. Bijauliya RK, Jain SK, Alok S, Dixit VK, Singh VK and Singh M: Macroscopical, microscopical and physico-chemical studies on leaves of Dalbergia sissoo Linn. (Fabaceae). Int J Pharm Sci Res 2017; 8(4):1865-73. https://doi.org/10.13040/IJPSR.09758232.8(4).1865-73. 